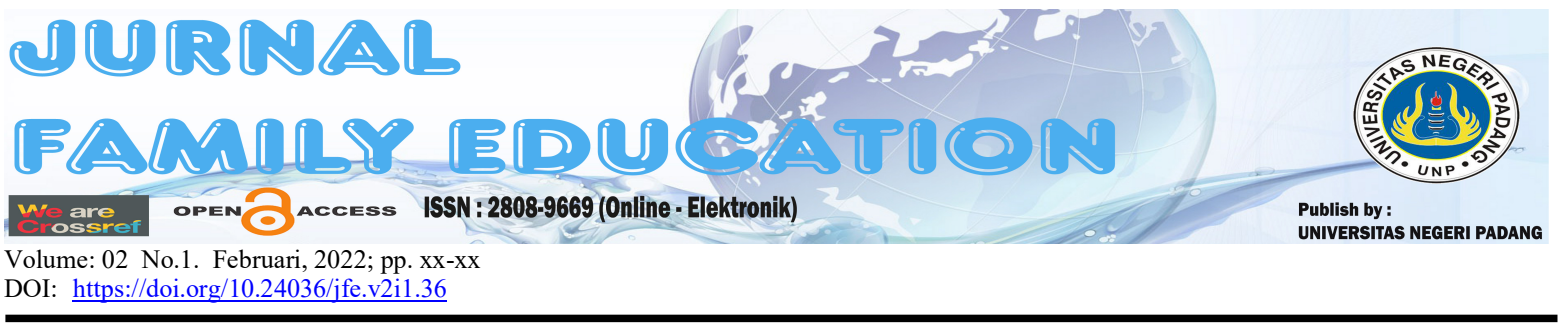

\title{
Hubungan Antara Bimbingan Orang Tua Dengan Minat Belajar Remaja Di Kampung Melayu Kec. Lubuk Basung Kab. Agam
}

\author{
Lidia Fitri, Vevi Surnati \\ Universitas Negeri Padang \\ *e-mail: lidiafitri463@gmail.Com
}

\begin{abstract}
This research is motivated by the low of parental guidance on adolescent learning interest in the Melayu Village, Lubuk Basung District, Agam Regency. aims to see a picture of adolescent learning interest, a picture of parental guidance and see the relationship between parental guidance and adolescent learning interest.This type of research is using a quantitative with a correlational approach. The population in this study were all teenagers in the Malay Village, Lubuk Basung District as many as 21 people. Sample was taken as much as 50\% of the population of 11 people. The results of this study indicate that parenting still low, adolescent learning interest is still lacking; and there is a significant relationship between parental guidance and adolescent learning interest in the Melayu Village, Lubuk Basung District, Agam Regency. It is recommended for parents to be able to provide encouragement and motivation for children to further improve and be more active in learning activities, as well as be a guide for further researchers.
\end{abstract}

Keywords: parental guidance and interest in learning

(7) \$) Licensees may copy, distribute, display and perform the work and make derivative works and remixes based on it only if they give the author or licensor the credits (attribution) in the manner specified by these. Licensees may copy, distribute, display, and perform the work and make derivative works and remixes based on it only for non-commercial purposes.

\section{PENDAHULUAN}

Pendidikan adalah salah satu pokok begitu mendasar bagi kehidupan manusia. Salah satunya pendidikan nonformal. Pendidikan nonformal adalah pendidikan berlangsung di luar aturan sekolah dan sengaja dirancang untuk mendidik siswa agar memiliki pengalaman, keterampilan, pengetahuan agar masyarakat bisa menghadapi perkembangan zaman.

Pada masa era globalisasi seperti sekarang ini pendidikan harus sangat diperhatikan, dimana perubahan teknologi yang semakin cangih sangat mempengaruhi prilaku anak.Untuk ituanak harus ada pengawasan atau bimbingan dari orang tua. Kita ketahui faktor penting dalam perkembangan pendidikan anak adalah peran orang tua, dimana keluarga menjadi wadah tempat anak dididik menjadi cerdas, berpengalaman, berilmu, dan berperilaku baik(Fahriati dan Suraini, 2018). Pendidikan keluarga adalah pendidikan non formal yang terselenggara oleh dan di dalam keluarga yang berbentuk pembelajaran dari satu tempat tinggal atau keturunan yang didalamnya terdapat ibu, ayah, anak-anak dan seterusnya(Maulani dan Bartin, 2021). Bimbingan orang tua akan meningkatkan minat belajar anak mereka.

Minat belajar merupakan suatu aktivitas yang dilaksanakan oleh peserta didik secara berkala dalam menjalan kegiatan pembelajaran. Slameto (2010), mengemukakan bahwasanya yang dimaksud dengan minat belajar ialah sebuah keinginan tetap dalam mengenang berbagai kegiatan yang telah dilakukan. 
Tabel 1. Minat Belajar Remaja Di Kampung Melayu

\begin{tabular}{|l|l|l|l|l|}
\hline \multirow{2}{*}{ No } & \multirow{2}{*}{ Tanggal } & \multicolumn{3}{|l|}{ Aspek yang diamati } \\
\cline { 3 - 5 } & & KMPR & KMP & KB \\
\hline 1 & $18-02-2021$ & 2 & 5 & 2 \\
\hline 2 & $19-02-2021$ & 6 & 5 & 2 \\
\hline 3 & $20-02-2021$ & 4 & 3 & 5 \\
\hline 4 & $4-03-2021$ & 4 & 2 & 4 \\
\hline 5 & $5-03-2021$ & 2 & 2 & 4 \\
\hline 6 & $6-03-2021$ & 3 & 3 & 5 \\
\hline 7 & $12-03-2021$ & 2 & 4 & 5 \\
\hline 8 & $18-03-2021$ & 3 & 3 & 4 \\
\hline 9 & $19-03-2021$ & 4 & 2 & 3 \\
\hline
\end{tabular}

Sumber: Data pengamatan terkait mengenai minat belajar di Kampung Melayu Kec. Lubuk Basung Kab. Agam

Keterangan:

KMPR :Keinginan mengerjakan PR

KMP :Kemauan mengulangi pelajaran

KB :Ketertarikan Belajar

Berdasarkan pengamatan awal pada tanggal 18 Maret 2021 di Kampung Melayu Kec. Lubuk Basung Kab.Agam, mengenai minat belajar remaja menyatakan bahwasanya banyak anak yang kurang memiliki minat belajar, dapat dilihat pada tabel 1. Berdasarkan fenomena diatas dapat disimpulkan bahwanya remaja di Kampung Melayu Kec. Lubuk Basung Kab.Agam memiliki minat belajar yang masih kurang, hal ini diduga dipengaruhi oleh bimbingan orang tua.

Belakangan ini banyak orang tua yang melupakan pendidikan keluarga. Hal ini setidaknya disebabkan oleh faktor kepentingan dunia, sibuk dengan pekerjaan dan pemikiran yang mendasari bahwa dengan materi berlimpah keluarga akan bahagia.

Lebih lanjut posisi orang tua pada membimbing anak belajar padatempat tinggal merupakanmembantu pendampingan. Pendampingan selaku eksklusif (oleh orang tua yang berlatar belakang pendidikan) merupakan memberi tau anak bahan ajar yang didalami, menemani anak dalam melaksanakan tugas rumah yang dibagikan sang guru, ataupun pendampingan lain yangmenaruh faedah untuk pembelajaran anak. Selaku tak eksklusif orang tua mampu menjalankan pengiringan pasif, walaupun tak turut belajar namun barangkali memahami harian atau buku, melakukan tugas tempat kerjadan seterusnya. Pendampingan misalnya sekarang relatif menaruhdorongan pada anak yang sedang belajar. Orang tua yangbukan mempunyai kesadaran mengenai pendidikan, dibutuhkanbisamenaruh semangat pada anak buat melaksanakan kegiatan belajar. Orang tua perlu harus ada waktu untuk meningkatkan minat belajar anak(Maulani dan Bartin, 2021).

Dari masalah diatas, maka penulis mengangkat judul "Hubungan antara Bimbingan Orang Tua dengan Minat Belajar Remaja Di Kampung Melayu Kec.Lubuk Basung Kab.Agam”.

\section{METODE}

Penelitian ini merupakan penelitian kuantitatif korelasional. Menurut Arikonto (2014), mengungkapkan bahwasanya penelitian korelasi yakni dimaksudkan guna menemukan ada ataupun tidaknya hubungan antar variabel, dilakukan untuk melihat hubungan antaran bimbingan orang tua dengan minat belajar remaja di Kampung Melayu Kec.Lubuk Basung Kab.Agam. Jumlah populasi sebanyak 31 orang, maka jumlah pengambilan sampel mengunakan teknik 
statified random sampling yaitu sebanyak 21 orang yang terdaftar di Kampung Melayu Kec. Lubuk Basung Kab.Agam.

\section{HASIL PENELITIAN DAN PEMBAHASAN}

\section{Hasil Penelitian}

Gambaran bimbingan orang tua di Kampung Melayu Kec.Lubuk Basung Kab.Agam.

Gambaran bimbingan orang tua dapat dilihat dari 2 variabel yakni: (1) pendampingan terdiri dari 10 item, (2) membantu terdiri dari 8 item. Dari indikator di atas jumlah keseluruhan butir item yang dijabarkan adalah 18 item dengan alternative jawaban tidak pernah (TP), jarang (JR),kadang-kadang (KD), sering (SR),Selalu (SL).Data dikelompokkan masing-masing berdasarkan skor, dan hitung persentasenya. Sampel dalam penelitian ini adalah 11 orang.Berikut ini data yang telah dikumpulkan tentang bimbingan orang tua.

\section{Pendampingan}

Gambaran tentang pendampingan dalam variabel bimbingan orang tua di Kampung Melayu Kec.Lubuk Basung Kab.Agam.

Gambar 1.

\section{HistogramPendampingan dalam Bimbingan Orang Tua di Kampung Melayu}

Kec.Lubuk Basung Kab. Agam

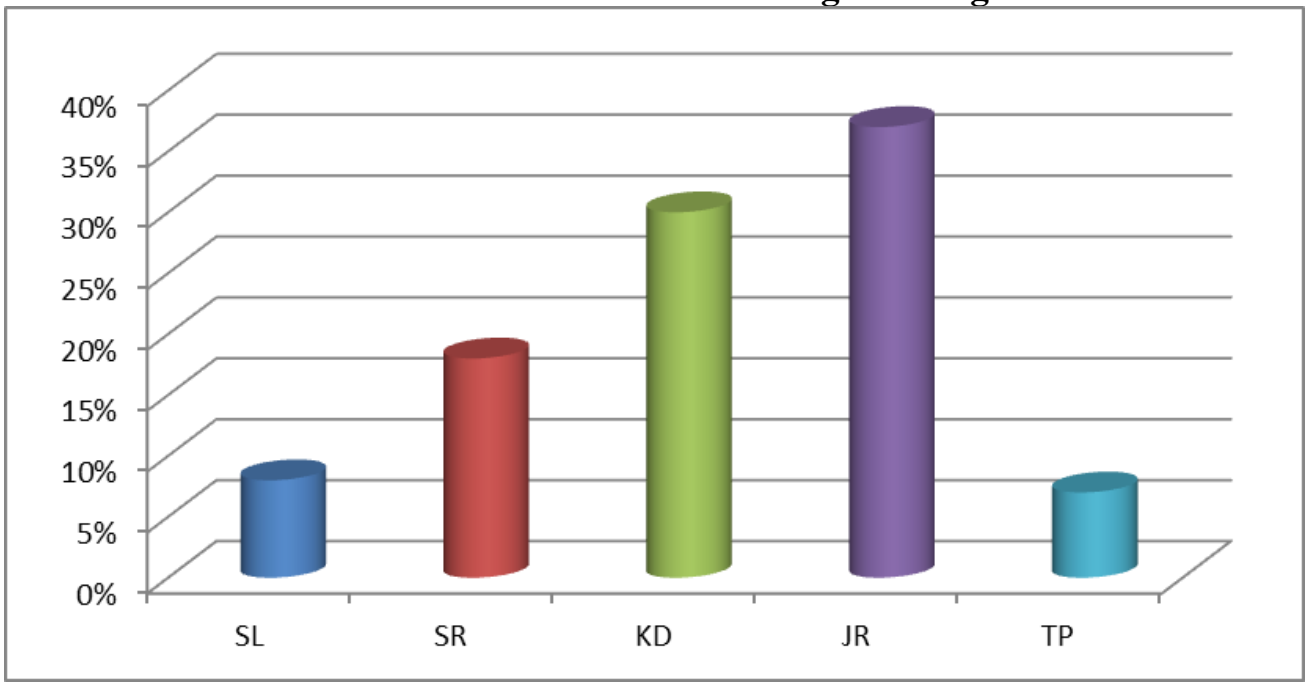

\section{Gambar 2.Histogram Hubungan Antara Bimbingan Orang Tua dilihat dari Aspek Pendampingan}

Dari gambar diatas dapat disimpulkan bahwa bimbingan orang tua dalam pendampingan kurang yaitu 37\% yang menjawab jarang.

\section{Membantu}

Gambaran tentang membantu dalam variabel bimbingan orang tua di Kampung Melayu Kec.Lubuk Basung Kab.Agam.

Gambar 2. 


\section{Histogram membantu dalam bimbingan orang tua di Kampung Melayu Kec.Lubuk Basung Kab. Agam}

Untuk lebih jelasnya dapat dilihat pada histogram berikut:

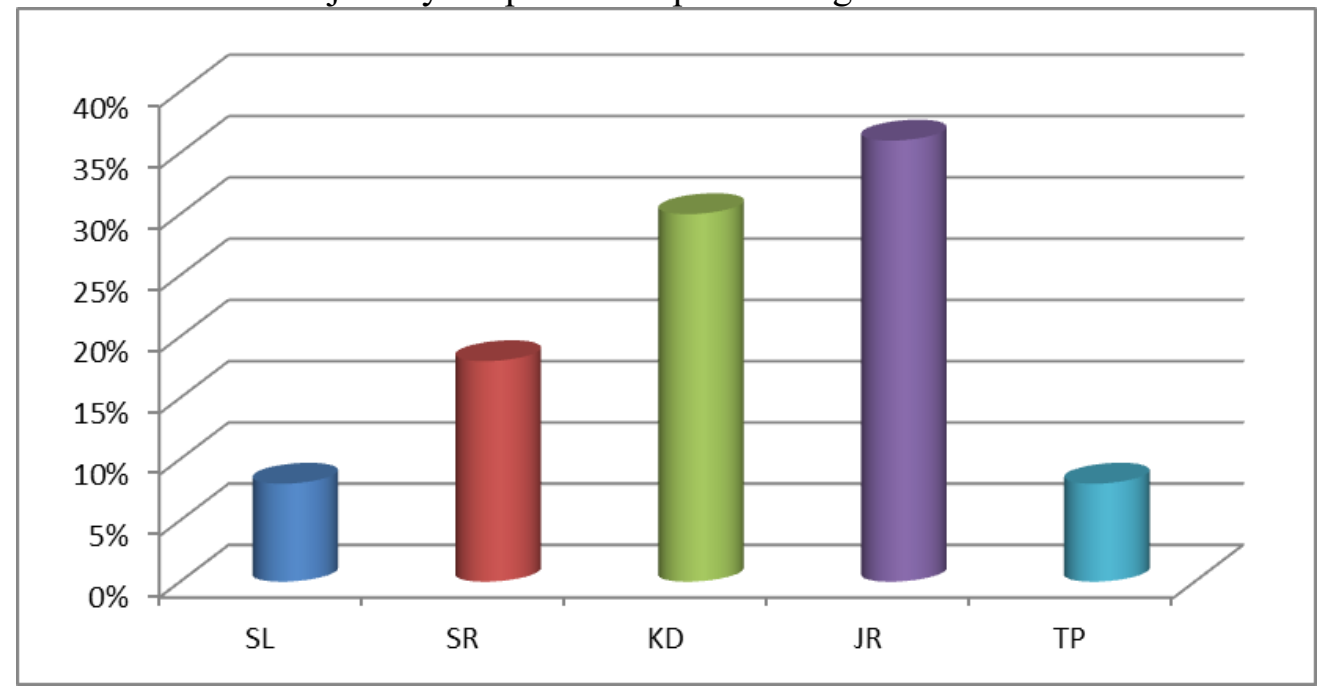

Gambar 2.Histogram Bimbingan Orang Tua dilihat dari Aspek Membantu

Dapat dilihat bimbingan orang tua dalam membantu diperoleh data responden sebanyak $8 \%$ responden menjawab selalu, 18\% responden menjawab sering, 30\% menjawab kadang-kadang, sebanyak 36\% responden menjawab jarang, dan $8 \%$ responden menjawab tidak pernah. Dapat disimpulkan bahwa bimbingan orang tua dalam membantutergolong kurang membantu yaitu 36\% yang menjawab jarang.

\section{Rekapitulasi bimbingan orang tua di Kampung Melayu Kec.Lubuk Basung Kab. Agam}

Rekapitulasi bimbingan orang tua di Kampung Melayu Kec.Lubuk Basung Kab.Agam sebagai berikut:

1. Gambar 3.

2. Rekapitulasi bimbingan orang tuadi Kampung Melayu Kec.Lubuk Basung Kab. Agam 


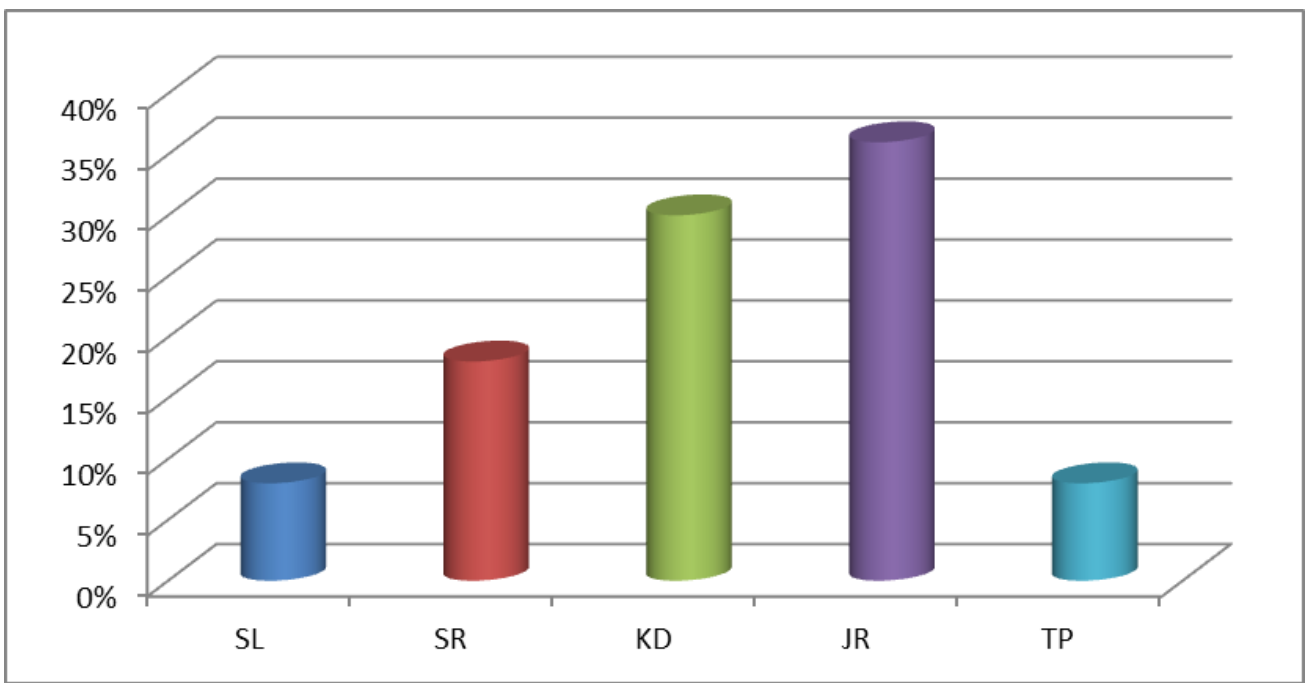

\section{Gambar 4.Rekapitulasi Bimbingan Orang Tua di Kampung Melayu Kec.Lubuk Basung Kab.Agam}

Dari gambar 3 dijelaskan bahwa bimbingan orang tua masih tergolong rendah.

\section{Gambaran minat belajar remaja di Kampung Melayu Kec.Lubuk Basung Kab.Agam}

Untuk mendapatkan gambaran minat belajar remaja, maka variabel minat belajar dilihat dari 4 sub variabel yakni: (1) perasaan senang terdiri dari 6 item, (2) ketertarikan melampirkan 7 item, (3) perhatian melampirkan 5 item, dan (4) kertelibatan melampirkan 4 item. Untuk lebih jelasnya hasil yang diperoleh dari pengelolaan data tentang minat belajar remaja di Kampung Melayu Kec.Lubuk Basung Kab. Agam dapat dilihat sebagai berikut:

\section{Perasaan senang}

Gambaran tentang perasaan senang dalam variabel minat belajar remaja di Kampung Melayu Kec.Lubuk Basung Kab.Agam.

Gambar 4.

HistogramPerasaan Senangdalam Minat Belajar Remajadi Kampung Melayu Kec.Lubuk Basung Kab. Agam

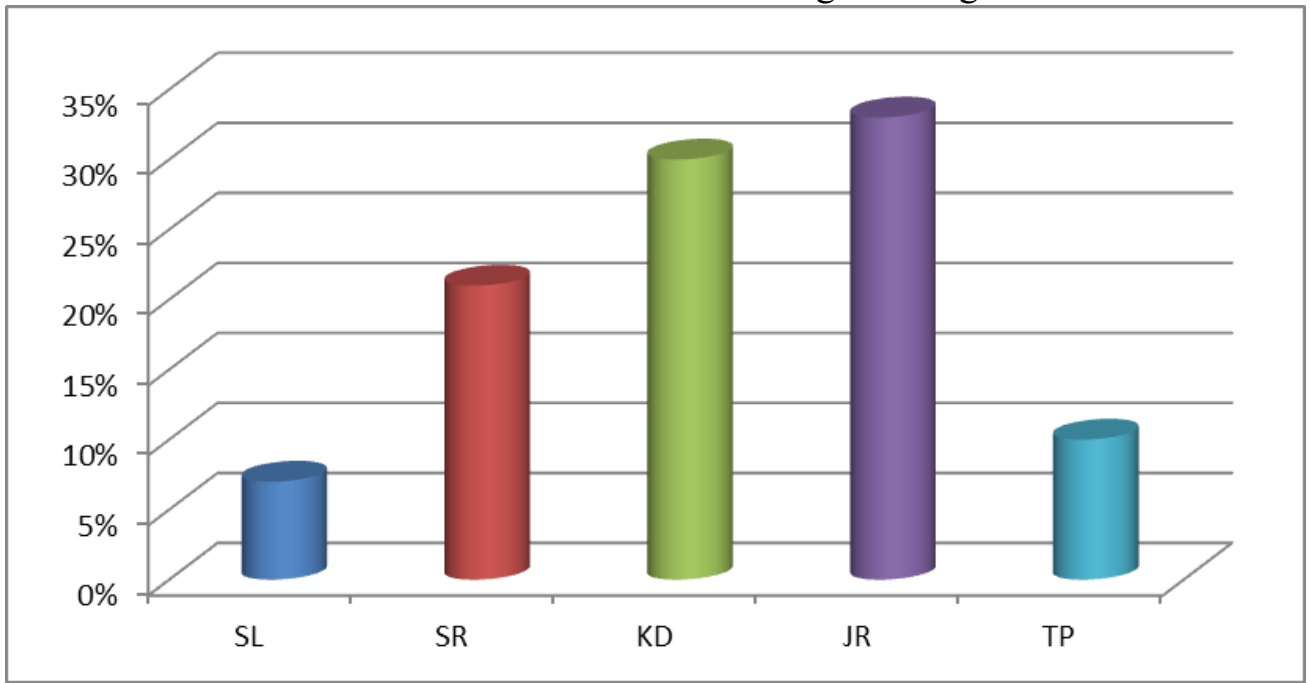


Gambar 4.Histogram Minat Belajar Remaja dilihat dari Aspek Perasaan Senang di Kampung Melayu Kec.Lubuk Basung Kab. Agam

Dari gambar 9 dapat dilihat bahwa minat belajar remaja dalam perasaan senang diperoleh data responden sebanyak 7\% menjawab untuk pilihan selalu, sebanyak $21 \%$ memberikan jawaban sering, $30 \%$ kadang-kadang, 33\% menjawab jarang, dan $10 \%$ menjawab tidak pernah. Dari gambar diatas dapat disimpulkan bahwa perasaan senang belajar remaja tergolong rendah yaitu $33 \%$ yang menjawab jarang.

\section{Ketertarikan}

Gambaran tentang ketertarikan dalam variabel minat belajar remaja di Kampung Melayu Kec.Lubuk Basung Kab.Agam.

3. Gambar 5.

4. Histogram ketertarikan dalam minat belajar remaja di Kampung Melayu Kec.Lubuk Basung Kab. Agam

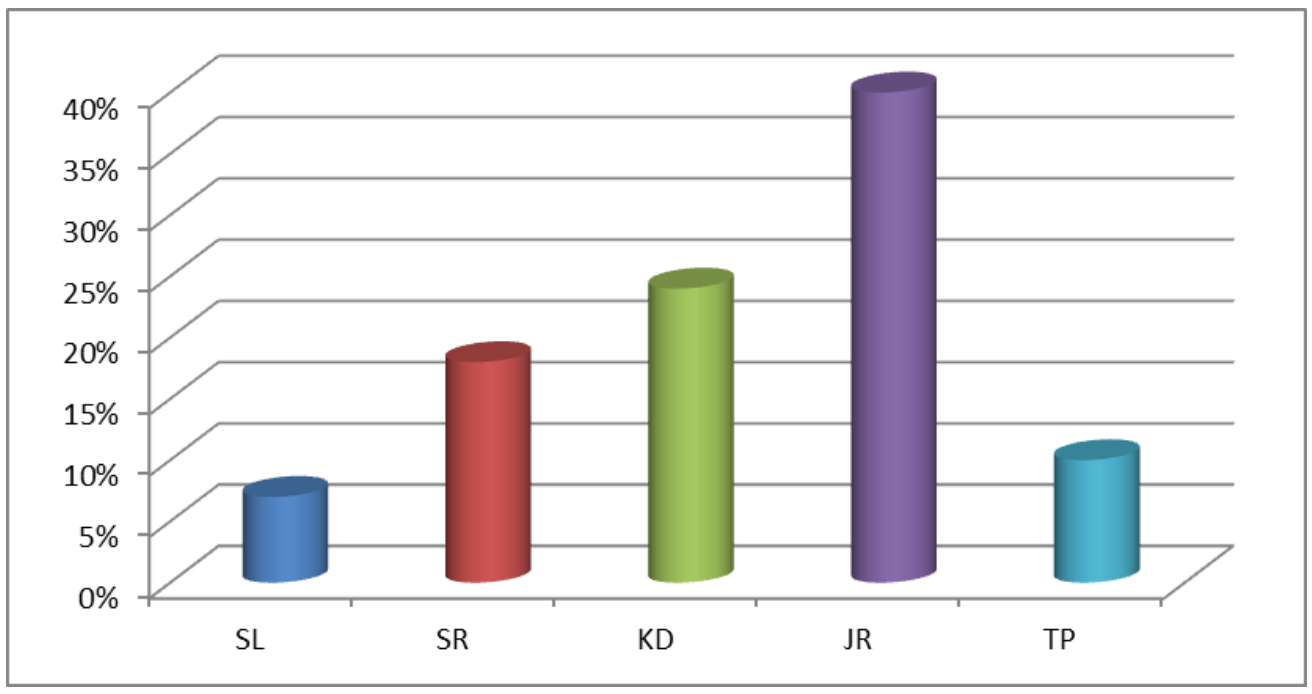

Gambar 5.HistogramMinat Belajar Remaja Dilihat Dari Aspek Ketertarikan Di Kampung Melayu Kec.Lubuk Basung Kab. Agam

Dari gambar 5 dapat dilihat bahwa minat belajar remaja dalam ketertarikan diperoleh data responden sebanyak $7 \%$ responde menjawab untuk pilihan selalu, $18 \%$ responden menjawab sering, 24\% menjawab kadang-kadang, 40\% menjawab jarang, dan 10\% memberikan jawaban tidak pernah. Dari gambar diatas dapat disimpulkan bahwa ketertatikan belajar remaja tergolong rendah yaitu $40 \%$ yang menjawab jarang. 


\section{Perhatian}

Gambaran tentang perhatiandalam variabel minat belajar remaja di Kampung Melayu Kec.Lubuk Basung Kab.Agam.

6. Gambar 6 .

7. HistogramPerhatian dalam Minat Belajar Remajadi Kampung Melayu Kec.Lubuk Basung Kab. Agam

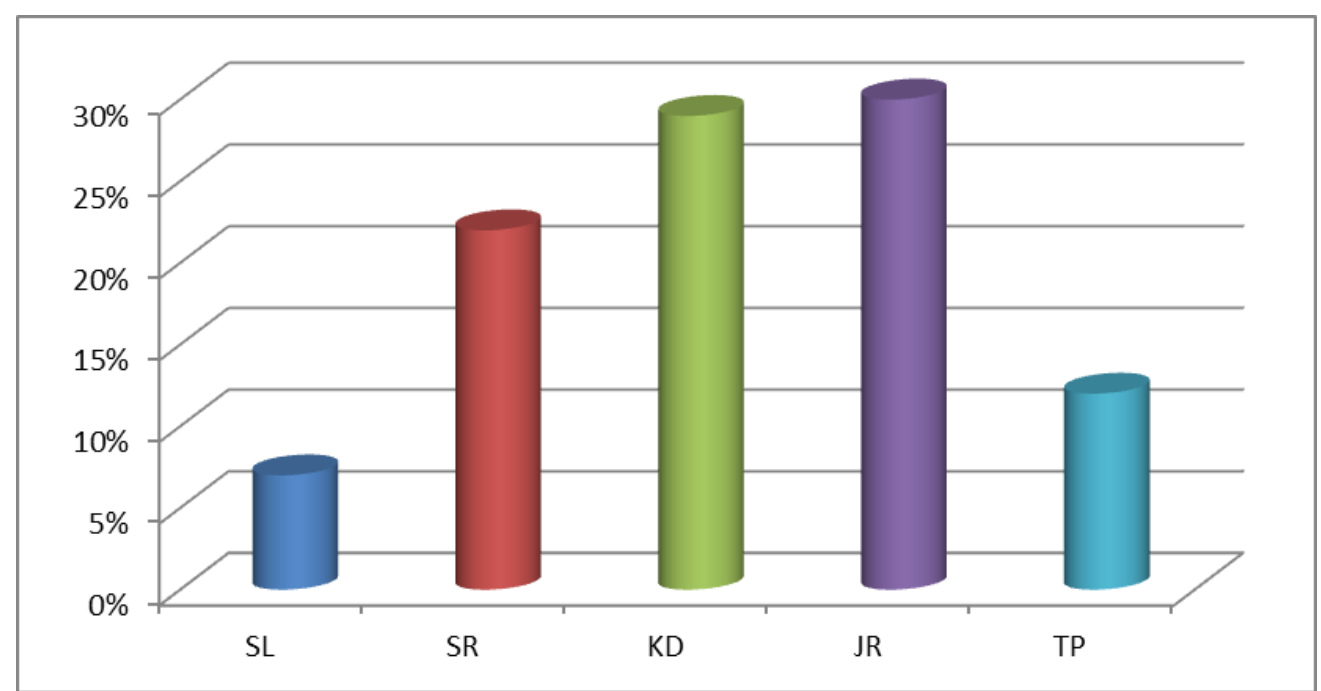

Gambar 6. Histogram Minat Belajar Remaja Dilihat Dari Aspek Perhatian Di Kampung Melayu Kec.Lubuk Basung Kab. Agam

Dari gambar 11 dapat dilihat bahwa minat belajar remaja dalam perhatian diperoleh data responden sebanyak $7 \%$ responde menjawab untuk pilihan selalu, sebanyak $22 \%$ responden menjawab sering, sebanyak 29\% menjawab kadang-kadang, sebanyak 30\% responden menjawab jarang, dan 12\% menjawab tidak pernah. Dari gambar diatas dapat disimpulkan bahwa perhatian belajar remaja tergolong rendah yaitu $30 \%$ yang menjawab jarang.

\section{8.}

\section{Keterlibatan}

Gambaran tentang keterlibatan dalam variabel minat belajar remaja di Kampung Melayu Kec.Lubuk Basung Kab.Agam.

Gambar 7.

\section{Histogram Keterlibatan dalam Minat Belajar Remajadi Kampung Melayu}

Kec.Lubuk BasungKab. Agam 


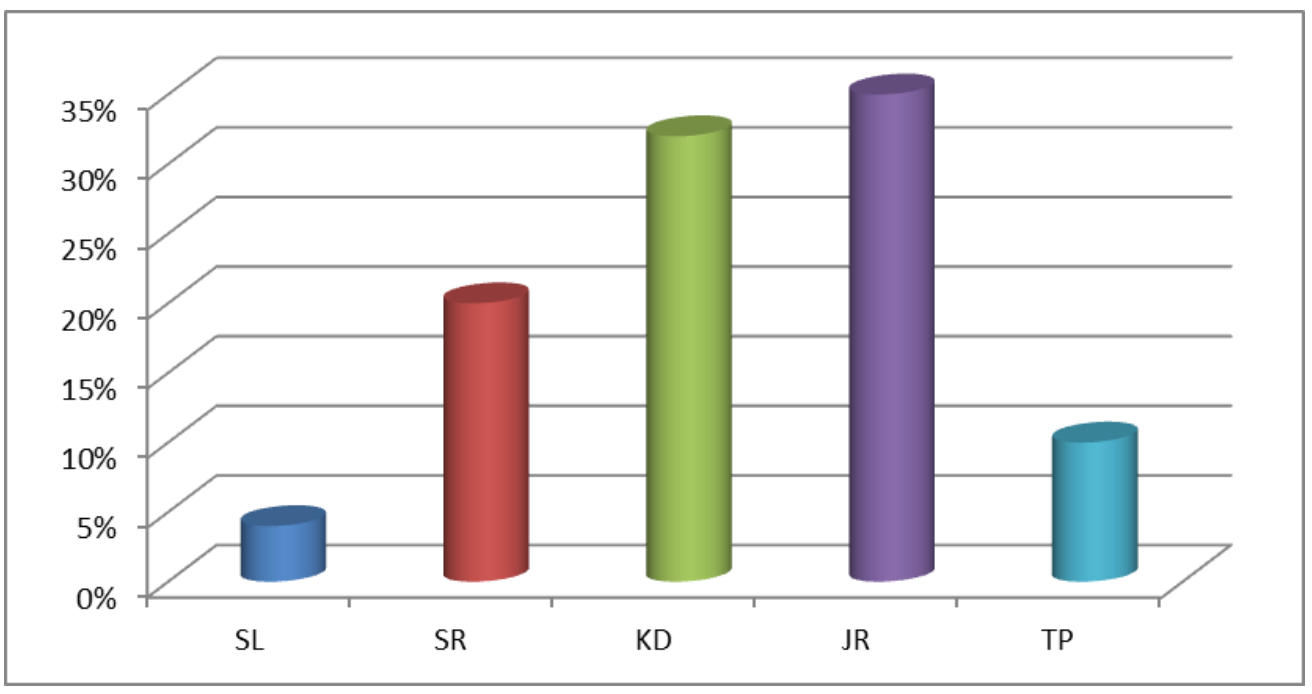

\section{Gambar 7. Histogram Minat Belajar Remaja Dilihat Dari Aspek Keterlibatan di Kampung Melayu Kec.Lubuk Basung Kab. Agam}

Dari gambar 7 dapat dilihat bahwa minat belajar remaja dalam keterlibatan diperoleh data responden sebanyak 4\% untuk pilihan selalu, 20\% menjawab sering, 32\% menjawab kadangkadang, sebanyak 35\% memberikan jawaban jarang, dan 10\% tidak pernah. Dari gambar diatas dapat disimpulkan bahwa keterlibatan dalam belajar remaja tergolong cukup yaitu 35\% yang menjawab jarang.

\section{Rekapitulasi minat belajar remaja di Kampung Melayu Kec.Lubuk Basung Kab. Agam}

Berikut Rekapitulasi minat belajar dapat dilihat sebagai berikut:

9. Gambar 5.

10. HistogramRekapitulasi minat belajar remaja di Kampung Melayu Kec.Lubuk Basung Kab. Agam 


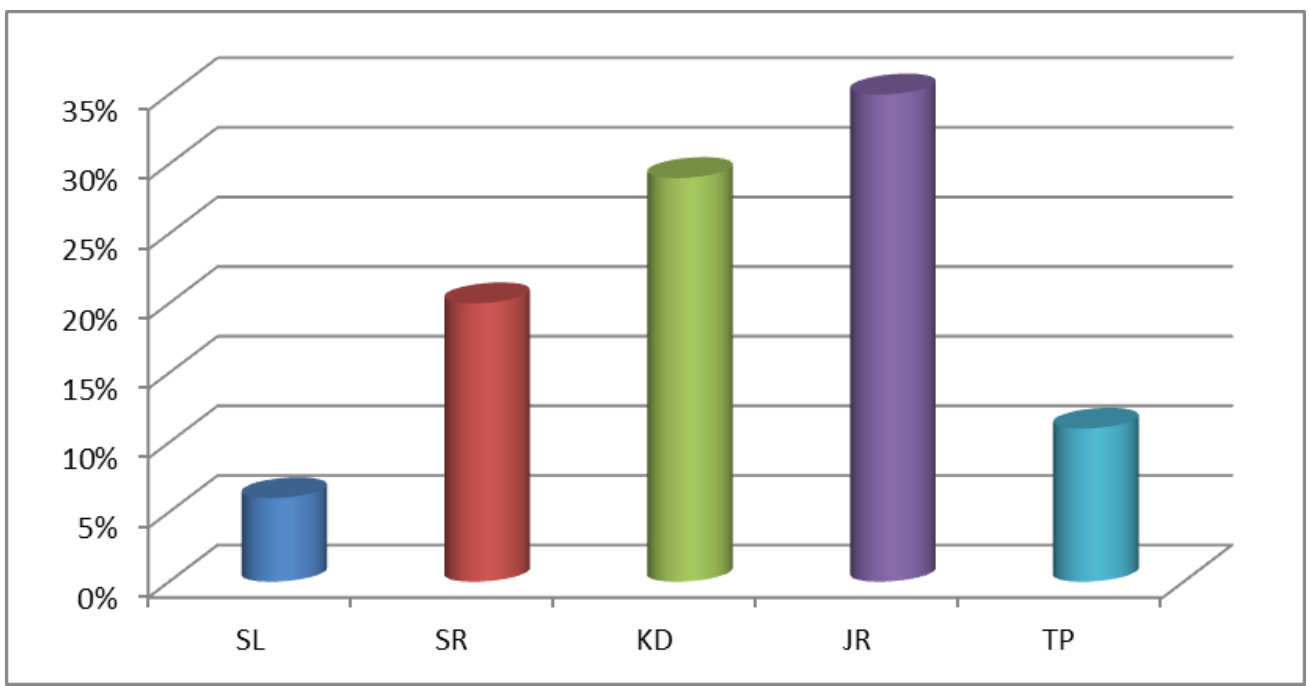

\section{Gambar 6. Histogram Rekapitulasi minat belajar remaja di Kampung Melayu Kec.Lubuk Basung Kab. Agam}

Dari gambar 8 dijelaskan bahwa rekapitulasi minat belajar remaja di Kampung Melayu Kec.Lubuk Basung Kab.Agam masih tergolong sangat rendah. Terbukti dari persentase responden memilih alternatif jawaban JR (jarang) yaitu 35\%. Bisa di ambil kesimpulan bahwa minat belajar remaja di Kampung Melayu masih sangat rendah.

11.

\section{Hubungan antara bimbingan belajar dengan minat belajar remaja di Kampung Melayu Kec.Lubuk Basung Kab.Agam}

Berdasarkan hasil analisa data menggunakan rumus rank order terdapat $\mathrm{r}_{\text {hitung }}=0,967$ serta sesudah dikonsultasikan sama nilai $r_{\text {tabel }} 0,456$ demi $n=11$ orang, tingkat kepercayaan $95 \%$, hingga mendapatkan korelasi yang positif yaitu $\mathrm{H}_{0}$ ditolak serta $\mathrm{Ha}_{\mathrm{a}}$ diterima. Jadi kesimpulannya bahwa terdapat hubungan antara bimbingan orang tua sama minat belajar remaja yang signifikan, di Kampung Melayu Kec. Lubuk Basung Kab.Agam.

\section{Pembahasan}

Sebagaimana telah dikemukan pada bagian hasil penelitian, menyatakan bahwasanya terdapat hubungan antara bimbingan belajar dengan minat belajar remaja di Kampung Melayu Kec.Lubuk Basung Kab.Agam. Berikut akan dijelaskan pembahasan hasil penelitian.

\section{Gambaran Bimbingan Orang Tua di Kampung Melayu Kec.Lubuk Basung Kab. Agam}

Berdasarkan rekapitulasi persentase sebelumnya bimbingan orang tua masih tergolong rendah. Digambarkan lebih banyak orang tua masih kurang memberikan pendampingan dan membantu anak pada pemberian perhatian, pengawasan, memberikan nasehat dan bimbingan.

Jika tidak memberikan bimbingan anak merasa kecewa dan mungkin frustasi melihat orang tuannya yang tidak pernah memberikan bimbingan kepada merekan. Orang tua harus memberikan berbagai motivasi kepada anak untuk meningkatkan rasa kepercayaan diri dan tanggung jawab atas tugasnya. 
Bersandarkan hasil penelitian disimpulkan bahwa pendampingan orang tua, menunjukkan kategorikan rendah. Hal ini musti untuk ditingkatkan lagi sehingga aktivitas belajar anak dirumah dapat meningkat, sehingga hasil belajar anak sesuai dengan harapan orang tua.

\section{Gambaran Minat Belajar Remaja di Kampung Melayu Kec.Lubuk Basung Kab. Agam}

Dapat terlihat bahwasannya minat belajar remaja di Kampung Melayu dilihat dari perasaan senang, ketertarikan, perhatian dan keterlibatan masih rendah. Menurut Yulidar, Syuraini\&Ismaniar (Efendi, 2018), atensi dalam memanfaatkan kegiatan sangat penting. Karena jika seseorang memiliki atensi yang tinggi, tentunya orang tersebut akan sering mengikuti kegiatan tersebut, dengan senang hati dan aktif. Ia melakukan apa yang diperlukan demi menggapai tujuan yang diinginkan. Seseorang yang mempunyai minat terhadap suatu hal, maka seseorang tersebut mempunyai rasa ketertarikan dan dorongan untuk melakukan aktivitas tanpa paksaan dari orang lain. (Djali dalam Nopaldi dan Setiawati, 2018)

Dapat disimpulkan dari hasil penelitian bahwa minat belajar remaja berada pada kategorikan rendah. Dapat dilihat dari kenderungan remaja memilih alternatif jawaban jarang pada aspek minat.

Hubungan Antara Bimbingan Orang Tua Dengan Minat Belajar Remaja di Kampung Melayu Kec. Lubuk Basung Kab. Agam

Berdasarkan analisis data terdapat hubungan yang signifikat antara bimbingan orang tua dengan minat belajar remaja, karena rhitung $>$ rtabel. Analisis data menunjukkan bahwa bimbingan orang tua memberikan pengaruh terhadap minat belajar remaja. Hal ini sebagaimana yang dikemukakan oleh Sianturi, Sinambela, dan Herliana (2020) bimbingan orang tua sangat diperlukan untuk menstimulasi motivasi belajar dalam diri anak didik hingga mencapai hasil belajar yang tertinggi, oleh karena itu bimbingan orang tua di rumah sangat berpengaruh pada kesiapan belajar anak dan penguatan dalam prosedur pembelajaran. Menurut Febriany dan Yusri (2013) Untuk mencapai hasil belajar yang baik di sekolah, anak harus memiliki minat belajar terlebih dahulu.Minat belajar dipengaruhi oleh materi pelajaran, teman sebaya, lingkungan, khususnya lingkungan keluarga terutama orang tua.

Penjelasan di atas dapat disimpulkan bahwa bimbingan orang tua dengan minat belajar remaja, termuat adanya afiliasi antara kedua variabel tersebut, secara teoritis jika orang tua memberikan bimbingan kepada anak maka minat belajar anak tinggi juga.

\section{KESIMPULAN}

Dari penelitian ini dapat disimpulkan, (1) Bimbingan orang tua masih rendah, (2) Minat belajar remaja masih rendah, dilihat dari perasaan senang, ketertarikan, perhatian dan keterlibatan remaja, dan (3) Terdapat hubungan yang signifikan antara bimbingan orang tua dengan minat belajar .

\section{DAFTAR PUSTAKA}


Lidia Fitri, Vevi Surnati

Arikunto, S. (2014). Metode Penelitian Kuantitatif, Kualitatif, dan Kombinasi (Mixed Methods). Bandung: Alfabeta.

Efendi, D., \& Ismaniar, I. (2021). Correlation Between Interest With Participation Of Toddlers Mothers In The Activities Of The Posyandu. Spektrum: Jurnal Pendidikan Luar Sekolah (PLS), 9(3), 438-444.

Febriany, R., \& Yusri, Y. (2013). Hubungan Perhatian Orangtua Dengan Motivasi Belajar Siswa Dalam Mengerjakan Tugas-Tugas Sekolah. Konselor, 2 (1).

Maulani, N. H., \& Bartin, T. (2021). Hubungan Antara Perhatian Orang Tua dengan Minat Belajar Siswa SMP pada Pembelajaran dari Rumah di RW II Kelurahan Parak Gadang Timur Kota Padang. Jurnal Pendidikan Tambusai, 5(1), 333-341.

Nopaldi, A., \& Setiawati, S. (2018). Hubungan Antara Motivasi Belajar Dengan Minat Belajar Warga Binaan Pada Keterampilan Menjahit Di Panti Sosial Karya Wanita Andam Dewi Solok. Spektrum: Jurnal Pendidikan Luar Sekolah (PLS), 6(4), 400-409.

Sianturi, R. R., Sinambela, M., \& Herliana, H. Hubungan Bimbingan Orang Tua Dan Minat Dengan Hasil Belajar Biologi Siswa Kelas XI IPA SMA Swasta Yayasan Pembinaan Keluarga Medan. Jurnal Pelita Pendidikan, 5(1).

Slameto. (2003). Belajar dan Faktor-Faktor Yang Mempengaruhinya, PT. Bina Aksara, Jakarta. 